\title{
Tüketici Hakları Farkındalığı ve Tüketici Bilinç Düzeyi: Denizli Örneği *
}

\author{
Consumer rights awareness and conscious consumer: Denizli case
}

\author{
Ahmet Soner PAKMAK ${ }^{1}$ \\ Duygu KOÇOĞLU 2a \\ ${ }^{1}$ Pamukkale Üniversitesi, İşletme Doktora Programı Öğrencisi, Denizli. aspakmak@gmail.com \\ ${ }_{2}^{2}$ Pamukkale Üniversitesi, İktisadi ve İdari Bilimler Fakültesi, Denizli. dkocoglu@pau.edu.tr \\ a Yazışılan yazar/Corresponding author
}

\section{Özet}

Tüketici hakları ve tüketici bilinci kavramları tüketici, üretici ve satıcılar açısından pazar sistemi dinamiklerinin etkin bir şekilde işlemesi için oldukça önem taşımaktadır. Bu çalışmanın amacı Denizli İlinde tüketici hakları farkındalı̆̆ın ve tüketici bilinç düzeyini tespit etmektir. Denizli ili merkez ilçelerinde yaşayan tüketicilere anket uygulanmış ve toplamda 388 anket analiz edilmiştir. Elde edilen veriler demografik değişkenlere göre farklılık analizleri ile test edilmiştir. Araştırma sonuçlar katılımcıların, tüketici hakları konusunda yeterli seviyede bilgi sahibi olmadıklarını göstermektedir. Ayrıca tüketici hakları farkındalı̆̆ı düşük olanların ekolojik çevre bilinçlerinin de düşük olduğu; ürün ve fiyat bilinçleri ile bilgi arayışlarmın ise daha yüksek olduğu tespit edilmiştir. Demografik özellikler açısından değişkenlere ilişkin elde edilen sonuçlar önemli ölçüde farklılık göstermektedir.

Anahtar kelimeler: Tüketici hakları, Tüketici farkındalı̆̆ı, Tüketici bilinci

JEL kodlarn: M31, M39.

\begin{abstract}
The concept of consumer rights and conscious consumer is crucial for the efficient handling of market system dynamics in terms of consumers, producers and sellers. The aim of this study is to determine consumer rights awareness and conscious consumer level in Denizli. A survey was conducted among the consumers living in the central districts of Denizli and 388 questionnaires were analized. The obtained data were tested by using differences analysis according to demographic variables. The research results show that consumers don't have enough knowledge about consumer rights. The results also show that those with low conscious consumer are higher in product conscious, price conscious and information seeking. At the same time it has been found that those with low conscious consumer have lower ecological environmental conscious. In terms of demographic characteristics, the results obtained regarding the variables differ considerably.
\end{abstract}

Keywords: Consumer rights, Consumer awareness, Consumer conscious

JEL codes: M31, M39.

\footnotetext{
* Bu çalışma “Tüketici Hakları Farkındalığı ve Tüketici Bilinç Düzeyi: Denizli' de Bir Araştırma” konulu yüksek lisans tezinden revize edilmiştir.
} 


\section{GİRIŞ}

Pazarlamanın tarihsel gelişimine bakıldığında 1950'lerde gelişmiş ülkelerde ortaya çıkan modern pazarlama anlayışı gelişen dünyaya entegre olmuş, işletmeler tüketici odaklı olmanın önemini anlamışlardır. Bu anlayışın önemli bir çıtısı "tüketici hakları" konusu olmuştur. Özellikle 1960'lardan sonra konuşulmaya başlanan tüketici hakları 1970'lerde hız kazanmış ve 1985 tarihli "Birleşmiş Milletler Evrensel Tüketici Hakları Bildirgesi" ile ciddiyete kavuşmuştur. Tüketici hakları farkındalığının artması ve çevre, sağlık gibi konularda tüketicinin bilinçlenmesi ile birlikte üreticiler toplumun uzun dönemli refahını düşünmeye zorlanmaktadır. Tüketici hakları farkındalığı bilinçli tüketimin oluşmasında önemli unsurlardan birisidir. Bu konuda devlet ve sivil toplum kuruluşları tarafından farklı kanallarla farkındalık yaratma ve bilinçlendirme faaliyetleri gerçekleştirilmektedir. Kamu spotu adı altında eğitici faaliyetler yürütülmekte, okullarda ders içeriklerinde yer almakta ancak gelişmiş ülkeler seviyesinde olduğu kadar konu üzerinde yeterince durulmamaktadır.

\section{TÜKETICII HAKLARI}

15 Mart 1962 tarihli Amerikan Kongresi' nde başkan John F. Kennedy tarafından güvenlik, bilgi alma, seçme ve temsil edilme olarak dört temel tüketici hakkının ilan edilmesiyle birlikte, literatürde tüketiciyi koruma gerekliliğinin temelleri atılmıştır (Makanyaze, 2015: 169). $\mathrm{ABD}^{\prime}$ de başlayan tüketici hareketi daha sonra Batı Avrupa'ya sıçramış, bir yandan tüketiciyi korumaya yönelik mevzuat yürürlüğe girerken, diğer taraftan tüketici örgütlenmeleri giderek yoğunlaşmıştır (Baykan, 1996: 17). Avrupa'da tüketiciyi korumanın temellerinin Avrupa Ekonomik Topluluğu'nun 14 Nisan 1975 tarihinde onaylamış olduğu program ile atıldığ1 kabul edilmektedir. Bu program ile birlikte tüketicinin sahip olduğu haklar güvenle tüketme, aydınlatılma, bilinçli bir seçim, zararların süratle tazmini ve sesini etkili bir şekilde duyurabilme olarak sıralanmıştır (Göle, 1979: 176). Tüketicilerin korunmasına yönelik evrensel nitelikte kabul görmüş yasal düzenlemelerin en dikkat çekeni 1985 tarihli "Birleşmiş Milletler Evrensel Tüketici Hakları Bildirgesi"dir. Bu bildirgede yayınlanan sekiz temel tüketici hakkı, ülkemizde 8 Eylül 1995 tarihinde yürürlüğe giren 4077 sayılı Tüketicinin Korunması Hakkında Kanun ile Türk tüketicisi için de geçerli hale gelmiştir (www.tudef.org.tr). Bu bildirgede ilan edilen sekiz temel tüketici hakkı şunlardır;

*Temel Gereksinimlerin Giderilme Hakk1

*Güvenlik Hakkı

*Bilgi Edinme Hakk1

*Seçme Hakk1

*Örgütlenme ve Temsil Edilme (Sesini Duyurma) Hakkı

*Tazmin Edilme Hakkı

*Eğitilme Hakkı

*Sağlıklı Bir Çevreye Sahip Olma Hakkı

Türkiye açısından tüketicinin korunmasına yönelik yasal mevzuatın temelini 1982 anayasası oluşturmaktadır (Baykan, 1996: 126). Tüketicinin korunması ile ilgili en önemli gelişme 4077 sayılı Tüketici Korunması Hakkında Kanun ile temin edilmiştir. Bu kanun da 06.03.2003 tarihinde kabul edilen, 4822 sayılı Tüketicinin Korunması Hakkında Değişiklik Yapılmasına Dair Kanun ile yeniden düzenlenmiştir. Bu alanda yapılan son düzenleme, 07.11. 2013 tarihinde kabul edilen, 6502 sayılı Tüketicinin Korunması Hakkında Kanun ile gerçekleşmiştir. 
(Özmumcu, 2015: 832). Tüketiciyi koruyan en etkili kuruluşlar tüketiciler tarafından kurulanlardır. Tüketici örgütlerinin kurulması, üretici ile tüketici arasındaki mesafeyi de kısaltarak tüketiciye kendi hakkını korunması konusunda söz sahibi olmasını sağlayacaktır (Hayta, 2007: 19).

Tüketici örgütleri, 4077 sayılı TKHK'nin 3. maddesinin (p) bendinde, tüketicinin korunması amacıyla kurulan dernek, vakıf veya bunların üst kuruluşları olarak tanımlanmıştır. 6502 sayılı TKHK bu tanım aynı şekilde korunmuş ve tüketici örgütlerine; çeşitli tüketici kuruluşlarına üye seçme yetkisi, dava hakkı ve düzenleme yapılırken görüş bildirme hakkı tanınmıştır (Aslan, 2016: 368). Tüketici örgütlerinin 20. yüzyılın ilk yarısında Amerika'da ortaya çıktığı ve sonrasında Japonya ile Avrupa Birliği ülkelerinde örgütlenmelerin devam ettiği görülürken Türkiye' de tüketiciler tarafından kurulmuş bağımsız tüketici örgütlerinin oluşumu ve gelişimi 1990’lı yıllara dayanmaktadır (Hayta, 2007: 15-17).

Tüketicilerin pazarda daha güçlü hale gelebilmesi ve gerektiğinde haklarını daha kolay savunabilmesi için tüketici örgütlerine üye olmalarında fayda vardır (Gülmez, 2006: 176). Nitekim tüketici örgütleri gerçekleştirmiş oldukları faaliyetler ile tüketicilerin sahip oldukları haklar konusunda farkındalık yaratarak, tüketici davranışlarını olumlu yönde etkilemekte ve daha bilinçli olmalarını sağlamaktadır (Şahin ve Kor, 2009: 122). Özellikle son yıllarda tüketici farkındalığı ve bilinçli tüketici gibi kavramlar hem uygulamada hem de teoride çok tartışılan kavramlar olmuştur.

\section{TÜKETİCI FARKINDALIĞI}

Tüketici farkındalığı, pazardaki değişim süreci boyunca bireysel tüketicilerin hakları ve sorumlulukları ile ilgilidir (Rousseau and Venter 1995: 18). İbarra ve Revilla (2014: 67) tüketici farkındalığını en basit şekilde tüketicilerin haklarını bilmesi olarak tanımlamışlardır. Tüketicilerin sahip oldukları haklar ve onları nasıl kullanacakları konusunda bilgi düzeylerinin artması; onları üretici ve satıcılar karşısında daha korunaklı hale getirecek, karşılaştıkları mağduriyetleri ortadan kaldıracak ve aynı zamanda bilinç düzeyini yükselterek pazar sisteminin dinamiklerini daha etkin bir şekilde işler hale getirecektir (Nart, 2008: 3).

Tüketici farkındalığının tam anlamıyla sağlanabilmesi için tüketicilerin hak ve menfaatlerinin korunması kadar bu haklara eşlik eden tüketici sorumluluğu da oldukça önemli yere sahiptir (Barksdale ve Darden, 1972: 31). Tüketiciler hak ve sorumluluklarının farkındayken şirketler tarafından sömürülmeye karşı korunurlar (Makanyeza, 2015: 168). Burada bahsi geçen sorumluluk kavramı Kumar (2016) tarafından; ürünün son kullanma tarihini, fiyatını, kalitesini, ağırlığını vb. özelliklerini kontrol etmek olarak ifade edilmiştir. Tüketicinin tam anlamıla farkındalık sahibi olabilmesi için hak ve sorumluluklarını beraberce benimsemesi gerekir. Tüketici üzerine düşen sorumlulukları benimsemediği takdirde uzun vadede haklarını koruyabilmesi çok zor olacaktır (Mohan ve Suganthi, 2013: 136).

Barksdale ve Darden (1972: 35) tüketici sorumluluğu konusunda; tüketicinin, haklı olduğu durumlarda şikayette bulunması gerekliliğini vurgulamışlardır. Böyle durumlarda tüketici genellikle konunun yeterince önemli olmadığını ve hakkını elde etmek için başvuracağı yasal sürecin zaman ve maliyet açısından külfetli olduğunu düşünmektedir (Cunnigham ve Cunnigham, 1976: 67). Tüketicilerin mağduriyet yaşadığı durumlarda hak arama yoluna gitmesi, işletmeler açısından müşteri ilişkilerini geliştirecek programların dizayn edilmesi 
sorumluluğunu doğuracaktır ve işletmeler gönüllü olarak tüketici şikayetlerine cevap vermezlerse mevzuat yoluyla daha fazla hükümet kontrolü ile karşı karşıya kalacaktır (Barksdale ve Darden, 1972: 35).

Kumar'a göre (2016: 339) farkındalık sahibi tüketici, satın alma ihtiyacını ve önceliğini belirleyerek, satın alma sözleşmesi, garanti şartları ve tazminat konularında bilgi edinmiş, tüketici hak ve sorumluluklarından haberdar olan, ürün ve hizmetleri doğru şekilde kullanan sağduyulu kişilerdir. Tüketici farkındalığı hakkında bir başka tanım ise Dickinson ve Shaver (1982) tarafından daha kapsamlı bir şekilde, üç tür bilginin farkındalığını içerecek şekilde yapılmıştır. Bunlar; ilgili ürün ve hizmet özellikleri, mevcut tüketici koruma kanunları, yönetmelikleri ve standartları ile olası başvuru kanallarıdır. Farkındalığın üç yönü de, ürünlerden memnuniyetsizlik riskini azaltacak sağlam seçimler yapmak için kritik önem taşımaktadır. Gerçekten de, tüketici farkındalığı tüketici problemlerine karşı birincil savunmadır (Dickinson ve Shaver, 1982: 241).

Bu bilgiler doğrultusunda tüketici farkındalığının temelini bilginin oluşturduğu söylenebilir. Aynı zamanda bilginin işletme ile tüketici ilişkisinin merkezinde olduğu ve her iki taraf için de önemli olduğu açktır. Bilgilenmiş tüketiciler kalitenin en etkili garantisidir, seçimleri işletmelerin rekabetini teşvik ederek üretim verimliliğini arttırır (Baldwin ve James, 2000: 140). Öyleyse tüketicinin bilgisi arttıkça farkındalığı, farkındalığı arttıkça da daha fazla bilgilenme ihtiyacı duyacağını söylemek mümkündür. Ürünler ve üreticilerle ilgili yasal hakları konusunda bilgisi ve farkındalığı artan tüketiciler bilinçli tüketici olarak pazarın dinamiklerini olumlu yönde etkileyecektir.

\section{BİLINÇLİ TÜKETICİ}

Bilinç kelimesi sözlükte insanın kendini ve çevresini tanıma yeteneği olarak tanımlanmıştır (TDK). Buradan yola çıkarak tüketici bilinci, pazar içerisinde ve satın alma sürecinde bu yeteneğin kullanılması olarak ifade edilebilir. Bilinçli tüketim, sosyal, çevresel, sağlık ve diğer pek çok kaygılardan oluşur. Kaygıların çoğu, sosyal olarak bilinçli davranışla ilgilidir. Toplumsal olarak bilinçli davranış, toplumun daha iyi olması anlamına gelir, dolaylı olarak hem çevresel kaygılar hem de sağlık kaygıları ile bağlantılıdır (Mayer 1976: 114). Carr ve diğg. (2012) bilinçli tüketimi kısaca, sürdürülebilirlik, sosyal adalet, kurumsal sorumluluk veya işçi hakları gibi değerleri dikkate alan ürünler veya hizmetlere yönelik yapılan seçim olarak ifade etmektedir. Gülmez (2006: 154), bilinçli tüketiciyi planlı, programlı, mantıklı tutum ve davranışlar sergileyerek temel ihtiyaçlarını ön planda tutan, sahip olduğu hakların farkında olan ve gerektiğinde kendini savunabilen, ürün kalitesi, fiyatı ve güvenliğine dikkat ederek, herhangi bir aldatıcı veya yanıltıcı etkiye kanmayan, her çeşit savurganlık ve israfın karşısında olan tüketici şeklinde açıklamıştır.

Literatürde yapılan bilinçli tüketici tanımlamalarında farklı noktalara vurgu yapıldığ görülmüştür. Bu konuda en önemli nokta, tüketicinin farkındalık sahibi olmadan bilinçli olamayacağ gerçeğidir. Bilinçli tüketici bilen, bildiklerini analiz eden ve bu doğrultuda hareket eden tüketicilerdir. Bilinçli tüketici bu yolda ilgisini sürekli canlı tutarak gerekli bilgi ve yenilikleri takip etme hedefindedir (Ferman, 1993: 8). Arıkan vd. (1996: 127)'ne göre iyi bir tüketici bilinçli hareket eden, satın alma sürecinde ihtiyaç ve olanakları ile çeşitli sosyal kaygıları arasında optimum ve rasyonel dengeyi kurabilen kişidir. 
En kapsamlı şekilde bilinçli tüketici kavramı, "Bir ürün ya da hizmeti satın alırken temel ihtiyaçlarına öncelik veren, satın alacağı mal ve hizmetlerin kaliteli, güvenli, standardı yüksek, sağlıklı ve çevre dostu olmasına dikkat eden, alışverişin nesnesi değil öznesi olduğunun bilincinde olan, tüketici olarak haklarını bilen, haklarına sahip çıkan ve savunan, medyanın ve reklâmların etkisinde kalarak yanlış tercihler yapmayan, israftan ve lüks tüketimden kaçınan, etik davranan, tüketim davranışının topluma ve çevreye olan etkilerinin farkında olan ve içinde bulunduğu toplumun gelişmesi için her türlü değişimi destekleyen açık fikirli bir birey "şeklinde tanımlanabilir (Babaoğul ve Buğday, 2016: 202).

Bilinçli tüketimi, sosyal bilinç, sağlık bilinci ve çevre bilinci olarak üç temel başlıkta incelemek mümkündür.

\subsection{Sosyal Bilinçli Tüketici}

Sosyal bilinçli tüketici, toplumun gelişimi için gerekli değişimlere yön veren açı fikirli kişi olarak tanımlanmaktadır (Anderson ve Cunningham 1972: 31). Webster'e göre (1975: 188) sosyal bilinçli tüketici; kişisel tüketiminin toplumsal sonuçlarını daima göz önünde bulunduran ve satın alma gücünü toplumsal değişimi sağlamak için kullanmaya çalışan tüketicidir. Soysal bilinçli tüketiciler eylemleriyle toplumdaki yaşam kalitesini yükseltmeye öncülük eden kişilerdir (Brooker, 1976: 107), sosyal tepkilerde yönlendirici roller üstlenerek daima ön cephede bulunurlar ve toplum yararı doğrultusunda yeniliklerin benimsenmesinde yardımcı durumdadırlar (Odabaşı ve Arıkan, 1996: 118).

Gelir, eğitim ve mesleki bakımdan topluma katkıda bulunmak için iyi bir konumda olan sosyal bilinçli tüketici kendine özgü yeteneği sayesinde bu konuda organize faaliyetler ya da bireysel davranışları ile aktif bir rol alır. Toplum kurallarına kendini uyarlayabilse de, uysal değildir ve çevresini ve dünyayı daha iyi hale getirmek için bir şeyler yapabileceğini düşünmektedir (Webster, 1975: 188-190).

Tüketim konusunda sosyal bilinç düzeyindeki artışla birlikte sosyoekonomik varlık konumundaki işletmelerin üretim stratejileri ve ürün politikalarında bu konuyu dikkate almaları, tüketicilerin ise tercihlerinde işletmelerin sosyal hassasiyetlerini dikkate almaları kaçınılmaz bir gerçektir (Yüce, 2013: 289). Bu bağlamda sosyal bilinçli tüketiciler, sosyal konularda sorumluluk üstlenen işletmelerin ürünlerini tercih ederek, topluma zarar verdiğine inandığ 1 ürünleri satın almaktan kaçınır (Mohr vd., 2001: 47). İşletmeler bu konuda daha güçlü bir pazarlama iletişimi sağlayabilmek için, pazar bölümlendirmesinde bir temel oluşturmak ve alternatif pazarlama stratejilerinin muhtemel etkinliğini ölçmek amacıyla sosyal bilinçli tüketicileri demografik ve sosyo-psikolojik niteliklerle ayırt etmelidir (Anderson ve Cunningham, 1972: 24).

Literatürde tüketicilerin sosyal bilinç düzeylerinin farklı demografik, sosyoekonomik vb. özellikleriyle ilişkilerini ölçen birçok çalışma yapılmıştır. Anderson ve Cunnigham (1972: 27), bu alanda dikkati çeken en kapsamlı uygulamalı çalışmalardan birini gerçekleştirmiş ve sosyopsikolojik değişkenlerin demografik değişkenlere göre tüketicilerin sosyal bilinç düzeylerini belirlemede daha etkili olduğunu saptamışlardır. Bu çalışmada yüksek meslek statüsüne sahip genç yaştaki yetişkinlerin sosyal bilinç düzeylerinin yüksek olduğu görülürken diğer demografik ve sosyoekonomik değişkenlerin daha karmaşık sonuçlar verdiği görülmüştür. Mohr vd. (2001: 56) tüketicilerin işletmelerin sosyal sorumluluk 
faaliyetlerine yönelik görüş, tutum ve davranışları üzerinden sosyal bilinç düzeylerini belirlemek için yapmış oldukları çalışmada katılımcılar dört ayrı grupta kategorilendirilmiştir. Katılımcılar arasında sosyal bilinç düzeyinin en yüksek olduğu grubun ağırlıklı olarak daha yüksek bir sosyoekonomik statü ve eğitim seviyesine sahip olan ve politik açıdan kendilerini liberal olarak değerlendiren tüketicilerden oluştuğu görülmüştür. Gonzalez (2009), sosyal bilinçli tüketicilerin farklı profil gruplarını belirlemek ve her grubun sosyal bilinç düzeylerini ortaya koymak için yapmış olduğu çalışmada; sosyal sorumluluk sahibi bireyler, uyanık bireyler, sosyal sorumluluk sahibi olmayan bireyler ve gelenekçi bireyler olmak üzere dört farklı tipoloji ortaya çıkmıştır. Singh (2009: 208), Hintli tüketicilerin demografik özellikleri ile sosyal bilinç düzeyleri arasındaki ilişkinin kapsamını ortaya koymak için yapmış olduğu çalışmada kent yaşamı süren tüketicilerin kırsal kesimde yaşayan tüketicilere oranla daha yüksek sosyal bilinç düzeyine sahip olduğunu saptamıştır.

\section{2. Çevre Bilinçli Tüketici}

Çevre kirliliği, doğal kaynakların kıtlı̆̆ı gibi konuların gerek akademisyenler gerekse çevre odaklı sivil toplum kuruluşları tarafından konuşulması ve tartışılması, tüketicilerin duyarlılığının artmasına neden olmuştur. Bener ve Babaoğul (2008: 6), çevre bilinçli tüketiciyi; çevre kirliliğine karşı kendi etkinliğini kavrayan, satın alma sürecinde tüm insanlık için sorumlu bir tutum gösteren tüketici olarak tanımlamaktadır. Çevre bilinçli tüketiciler, işletme uygulamalarının çevreye olan etkileri konusunda bilgi sahibi olmak isterler. Bu konuda işletmelerin söylemleri ile eylemlerinin tutarlılığını analiz eden çevre bilinçli tüketicilerin, olumsuz bir durum karşısında bu işletmelere karşı güven duygularının ve satın alma niyetlerinin azaldığı görülür (Straughan ve Roberts, 1999: 149-150). Çevre bilinçli tüketiciler, işletmelerin çevreci uygulamaları karşısında, yüksek düzeyde algılanan tüketici etkinliği sergileyerek, bu işletmelere ve ürünlerine karşı sadakat gösterip duygusal bağlar oluşturabilirler (Jang vd., 2015: 149-153).

Geleneksel düşünceye göre, çevre bilincinin artmasıyla birlikte üretken faaliyetlerde daha az kaynak kullanıldığı, tüketim olayında ise daha fazla kaynak harcanması sebebiyle ekonomik büyümenin engellendiği görüşü savunulurken, günümüzde çevre bilinçli tüketim anlayışının sürdürülebilir ekonomik kalkınmaya olumlu yönde katkı sağlanacağı görüşü hakimdir (Shieh vd., 2014: 151). Çevresel bilinci yüksek olan ve yeşil tüketici davranış biçimini benimseyen tüketicilerin, bu özelliklerinin temelini oluşturan faktörlerden birinin genel tüketici farkındalığının olduğu ve tüketici farkındalığının çevre bilinçli tüketim davranışını olumlu yönde etkilediği söylenebilir (Huang vd., 2014: 147).

Tüketicilerin çevre konusundaki endişeleri, yaşam biçimine, değerlerine ve dolayısıyla satın alma kararlarına yansımaktadır. Çevre konusunda endişeleri olan tüketiciler, gerektiğinde daha fazla harcama yapıp, ekolojik ve geri dönüşümlü ürünleri tercih ederek çevre korumaya yönelik faaliyetlerde bulunurlar (Fraj ve Martinez, 2006: 133-134). Çevre ile ilgili konulara daha fazla duyarlılık gösteren tüketiciler, işletmelerin de aynı duyarlılığı göstermelerini beklemektedirler (Aracıoğlu ve Tatlıdil, 2009: 439).

Schlegelmilch vd. (1996: 35-44) ekolojik çevre bilinç düzeyi ile ekolojik bilgi, ekolojik tutum, siyasi eylem ve geri dönüşüm davranışı kriterleri arasındaki ilişkiyi analiz etmiş ve tüm faktörlerin genel tüketici ekolojik çevre bilinç düzeyi ile doğrudan ilişki içerisinde olduğunu saptamıştır. Ancak öğrencilerin çevre bilinçli davranışlarının, ekolojik bilgi ve geri dönüşüm 
davranış düzeyleri ile güçlü bir ilişkisinin olmadığı tespit edilmiştir. Straughan ve Roberts'in (1999: 565) 235 üniversite öğrencisine uyguladıkları araştırmada psikografik değişkenlerin demografik değişkenlere oranla ekolojik çevre bilinç düzeyinde daha önemli etkileri olduğu görülmüştür. Bu çalışmada fedakarlık, çevresel kaygı ve tüketici etkinliğinin algılanması değişkenlerinin çevre bilinç düzeyi ile olumlu yönde ilişkisi olduğu belirlenmiştir (Straughan ve Roberts, 1999: 566).

Ay ve Ecevit (2005: 247-256)'in yapmış oldukları, çevre bilinçli tüketici davranışlarının demografik ve psikografik değişkenlerle analiz edildiği çalışmada çevre bilinçli tüketici davranışı üzerindeki demografik değişkenlerin etki sırasının gelir, eğitim, yaş ve cinsiyet şeklinde olduğu sonucu ortaya çıkmıştır. Çabuk vd.(2008:97) tarafından yapılan çevre bilinç düzeyinin sosyo-demografik değişkenler doğrultusunda analiz edildiği araştırma sonuçlarına göre; kadın, evli, genç, yüksek hane geliri ve eğitim seviyesine sahip bireylerin daha yüksek düzeyde ekolojik çevre bilincine sahip olduğu belirlenmiştir. Huang vd.'nin (2014: 139-145) yapmış oldukları çalışmada gençlerin ve erkeklere oranla kadınların daha yüksek düzeyde ekolojik çevre bilincine sahip olduğu saptanmıştır.

\subsection{Sağlık Bilinçli Tüketici}

Sağlık bilinci, kişinin kendi sağlığı için teyakkuzda olduğunu yansıtan bir kavramdır. Sağlık bilincine sahip bireyler sağlık durumlarının farkındadır ve daima sıhhatleri için endişelenmekte (Kaynak ve Ekşi, 2014: 773), varlıklarını sürdürmek için yaşam biçimlerini ve tercihlerini buna göre şekillendirmektedir (Dutta-Bergman, 2004: 276). Sağlık endişesi ve bilinci gıda seçimlerini etkilemekte, sağlık bilinci artan tüketiciler, bazen kendileri için tercih ettikleri tatlardan ziyade sağlık veya kilo bilinci ile gıda seçimi yapmaktadır (Bakke vd., 2016: 93). Bu doğrultuda doğal, işlenmemiş gidalara yönelmektedirler (Jay-Russel, 2010: 1418).

Son yıllarda gıda kaynaklı hastalıklar ve gıda skandallarının artması birçok tüketicinin sağlığından endişe etmesine ve gida ürünlerine olan güvenlerini kaybetmesine sebep olmuştur (Bektaş vd., 2011: 470). Üreticilere yönelik oluşan güven kaybıyla, tüketiciler kendisine sunulan ürünlere karşı daha şüpheci yaklaşım sergilemektedirler. Ayrıca televizyon kanallarında doktorların ve diyetisyenlerin yer aldığı programların da sağlık bilinci üzerinde olumlu etkisi olmuştur. Bu bağlamda tüketicinin sağlıklı beslenmek, sağlıklı görünmek ve sağlıklı yaşamak konusunda bilinç düzeyinin arttığını söylemek mümkündür. Geçmişte kendisine sunulan sanayi ürünlerini güvenle kullanan tüketiciler şimdi artık daha organik ürünlere yönelmektedirler. Ancak hala damak zevkine odaklı bilinçsiz beslenen ve tüketen tüketici kitleleri olduğu da inkar edilemez bir gerçektir.

\section{Metodoloji}

Araştırmanın amacı, Denizli ilinde tüketici hakları farkındalığını belirlemek, tüketici bilinç düzeyini; ürün bilinci, fiyat bilinci, bilgi düzeyi ve ekolojik çevre bilinci boyutlarıyla ölçmektir. Ayrıca, tüketici hakları farkındalığı ve tüketici bilinç düzeyi arasındaki ilişkiyi demografik değişkenler ile birlikte analiz etmektir.

Araştırmanın amacına yönelik oluşturulan araştırma soruları aşağıda sıralanmıştır;

Soru 1: Tüketici hakları bilgisi demografik değişkenlere göre (cinsiyet, eğitim durumu, gelir düzeyi, yaş, mesleki durum) farklılık göstermekte midir? 
Soru 2: Ürün bilinci demografik değişkenlere göre (cinsiyet, eğitim durumu, gelir düzeyi, yaş, mesleki durum) farklılık göstermekte midir?

Soru 3: Ürünler hakkında bilgi arayışı demografik değişkenlere göre (cinsiyet, eğitim durumu, gelir düzeyi, yaş, mesleki durum) farklılık göstermekte midir?

Soru 4: Fiyat bilinci demografik değişkenlere göre (cinsiyet, eğitim durumu, gelir düzeyi, yaş, mesleki durum) farklılık göstermekte midir?

Soru 5: Ekolojik çevre bilinci demografik değişkenlere göre (cinsiyet, eğitim durumu, gelir düzeyi, yaş, mesleki durum) farklılık göstermekte midir?

Soru 6: Tüketici hakları farkındalığı düzeyine göre ürün bilinci düzeyi farklılık göstermekte midir?

Soru 7: Tüketici hakları farkındalığı düzeyine göre bilgi araştırma düzeyi farklılık göstermekte midir?

Soru 8: Tüketici hakları farkındalığı düzeyine göre fiyat bilinci farklılık göstermekte midir?

Soru 9: Tüketici hakları farkındalığı düzeyine göre ekolojik çevre bilinci düzeyi farklılık göstermekte midir?

Soru 10: Tüketici bilinç düzeyi demografik değişkenlere göre (cinsiyet, eğitim durumu, gelir düzeyi, yaş, mesleki durum) farkl1lık göstermekte midir?

Araştırmada nicel araştırma yöntemlerinden yüz yüze anket tekniği kullanılmıştır. Tüketicilere uygulanmış olan ve 5 ayrı boyutu içeren anket formunda 30 soru yer almaktadır. Tüm anket sorularında 5'li Likert ölçeği kullanılmıştır. Katılımcıların sahip oldukları haklar konusundaki bilgi düzeyini ölçmek için Nart (2008) tarafından geliştirilen tüketici haklarına yönelik bilgi düzeyi ölçeği kullanılmıştır. Tüketicilerin ürün ve fiyat bilinci ile bilgi arayış çabalarını ölçmek için ise Rousseau ve Venter (1995) tarafından geliştirilen ve Makanyeza (2015)'nın çalışmasında da kullanılan ölçekler uygulanmıştır. Kullanılan ölçeklerde tüketicilerin fiyat bilinci düzeylerinin analizinde orijinal kaynakta geçen fiyat farkındalığı ve pazarlık avcısı boyutları birleştirilip indirimle ilgili bazı ifadeler çıkarılmıştır. Aynı zamanda tüketicilerin çevresel bilinç düzeyini ölçmek amacıyla Maloney vd. (1975)'in geliştirdikleri, Fraj ve Martinez (2006)'in de çalışmalarında kullandıkları “Ekolojik Tutum Ölçeği” kullanılmıştır.

Araştırmanın evrenini Denizli ili merkez ilçelerinde (Pamukkale-Merkezefendi) yaşayan tüketiciler oluşturmaktadır. Örneklem seçiminde kolayda örneklem yöntemi kullanılmış olup toplamda 420 kişi ile görüşme yapılmıştır. Anket formlarından 32 tanesi değerlendirilmeye uygun bulunmamış ve geriye kalan 388 anket ile analizler yapılmıştır. \%95 güven aralığında 1000.000 ve üzeri anakütle büyüklüğü için 384 örnek sayısının yeterli olduğu görüşünden hareketle (Saunders vd., 2000: 156; Gegez, 2010: 220), Denizli ilinin toplam nüfusunun 1.018.735 olduğu dikkate alındığında, çalışmada kabul edilebilir örneklem sayısına ulaşıldığ söylenebilir.

\section{ARAŞTIRMANIN BULGULARI}

Araştırmada kullanılan ölçeklerin güvenirlik analizleri sonuçları Tablo 1'de yer almaktadır. Araştırmanın güvenilirlik analizi sonuçları incelendiğinde; tüketici hakları farkındalığı 
ölçeğinin iç tutarlık katsayısı 0,919, ürün bilgisi ölçeğinin iç tutarlık katsayısı 0,711, bilgi araştırma ölçeğinin iç tutarlık katsayısı 0,681, fiyat bilinci ölçeğinin iç tutarlık katsayısı 0,825 ve ekolojik çevre bilinci ölçeğinin iç tutarlık katsayısı 0,937 olduğu görülmektedir. Bu sonuçlara göre tüm ölçeklerin güvenilir olduğunu ve ankete katılan kişilerin tutarlı cevaplar verdiğini söylemek mümkündür.

Tablo 1. Güvenirlik Analizi Sonuçları

\begin{tabular}{|c|c|c|c|c|}
\hline & Maddeler & $\begin{array}{l}\text { Düzeltilmiş } \\
\text { madde-toplam } \\
\text { Korelasyonu }\end{array}$ & $\begin{array}{l}\text { Madde } \\
\text { silindiğinde } \\
\text { Cronbach Alfa }\end{array}$ & $\begin{array}{l}\text { İç Tutarlılık } \\
\text { Katsayısı } \\
\text { (Cronbach }\end{array}$ \\
\hline \multirow{11}{*}{$\begin{array}{l}\text { Tüketici Hakları } \\
\text { Farkındalığı }\end{array}$} & Madde 1 & ,688 & ,912 & \multirow{11}{*}{,919 } \\
\hline & Madde 2 & ,761 & ,908 & \\
\hline & Madde 3 & ,773 & ,907 & \\
\hline & Madde 4 & ,689 & ,911 & \\
\hline & Madde 5 & ,683 & ,913 & \\
\hline & Madde 6 & ,771 & ,908 & \\
\hline & Madde 7 & ,708 & ,911 & \\
\hline & Madde 8 & 604 & ,916 & \\
\hline & Madde 9 & 618 & 916 & \\
\hline & Madde 10 & ,682 & ,912 & \\
\hline & Madde 11 & ,612 & ,915 & \\
\hline \multirow{5}{*}{ Ürün Bilinci } & Madde 12 & ,355 & ,704 & \multirow{5}{*}{,711 } \\
\hline & Madde 13 & ,486 & 662 & \\
\hline & Madde 14 & ,658 & ,570 & \\
\hline & Madde 15 &, 352 & ,704 & \\
\hline & Madde 16 &, 545 & ,632 & \\
\hline \multirow{5}{*}{ Bilgi Araştırma } & Madde 17 & ,427 & 635 & \multirow{5}{*}{,681 } \\
\hline & Madde 18 & ,494 & ,609 & \\
\hline & Madde 19 & ,364 & ,677 & \\
\hline & Madde 20 & 452 & ,629 & \\
\hline & Madde 21 & ,489 & 605 & \\
\hline \multirow{5}{*}{ Fiyat Bilinci } & Madde 22 & ,551 & ,810 & \multirow{5}{*}{825} \\
\hline & Madde 23 &, 531 & ,817 & \\
\hline & Madde 24 & ,660 & ,779 & \\
\hline & Madde 25 & ,740 & ,752 & \\
\hline & Madde 26 & 656 & ,785 & \\
\hline \multirow{4}{*}{$\begin{array}{l}\text { Ekolojik } \\
\text { Bilinci }\end{array}$} & Madde 27 & ,860 & ,916 & \multirow{4}{*}{,937 } \\
\hline & Madde 28 & ,868 & ,913 & \\
\hline & Madde 29 & ,899 & ,904 & \\
\hline & Madde 30 & ,783 & 940 & \\
\hline
\end{tabular}


Değerlendirmeye alınan anketlere ait katılımcıların demografik özellikleri Tablo 2' de yer almaktadır.

Tablo 2. Katılımcıların Demografik Özellikleri

\begin{tabular}{|c|c|c|c|}
\hline \multicolumn{2}{|c|}{ Demografik değişkenler } & \multirow{2}{*}{$\begin{array}{c}\mathbf{N} \\
177\end{array}$} & \multirow{2}{*}{$\begin{array}{c}\% \\
45,6\end{array}$} \\
\hline \multirow{3}{*}{ Cinsiyet } & Kadın & & \\
\hline & Erkek & 211 & 54,4 \\
\hline & Toplam & 388 & 100,0 \\
\hline \multirow{5}{*}{ Yaş } & 25 alt1 & 69 & 17,8 \\
\hline & $25-34$ & 155 & 39,9 \\
\hline & $35-44$ & 72 & 18,6 \\
\hline & 45 üstü & 92 & 23,7 \\
\hline & Toplam & 388 & 100,0 \\
\hline \multirow{8}{*}{ Eğitim Düzeyi } & İlköğretim & 57 & 14,7 \\
\hline & Ortaokul & 13 & 3,4 \\
\hline & Lise & 75 & 19,3 \\
\hline & Önlisans & 39 & 10,1 \\
\hline & Lisans & 172 & 44,3 \\
\hline & Lisansüstü & 44 & 11,3 \\
\hline & $\overline{\text { Cevapsiz }}$ & 1 & 0,03 \\
\hline & Toplam & 388 & 100,0 \\
\hline \multirow{7}{*}{ Mesleki Durum } & Öğrenci & 63 & 16,2 \\
\hline & Özel Sektör & 207 & 53,4 \\
\hline & Kamu Çalışanı & 51 & 13,1 \\
\hline & Emekli & 43 & 11,1 \\
\hline & Ev Hanımı & 20 & 5,2 \\
\hline & İşsiz & 4 & 1,0 \\
\hline & Toplam & 388 & 100,0 \\
\hline \multirow{5}{*}{ Gelir Düzeyi } & 2501 TL alt1 & 95 & 24,5 \\
\hline & $2501-3500 \mathrm{TL}$ & 104 & 26,8 \\
\hline & $3501-4500 \mathrm{TL}$ & 89 & 22,9 \\
\hline & 4500 TL üstü & 100 & 25,8 \\
\hline & Toplam & 388 & 100,0 \\
\hline
\end{tabular}

Araştırmanın boyutlarına ilişkin ortalamalar Tablo 3'de yer almaktadır. Buna göre, katılımcıların ürün ve fiyat bilinci ile bilgi arayışının yüksek düzeyde, ekolojik çevre bilincinin orta düzeyde, tüketici hakları farkındalığının düşük düzeyde olduğu görülmektedir.

Tablo 3. Katılımcıların Tüketici Bilinç Düzeyini Belirleyen Boyutlar

\begin{tabular}{lccc}
\hline & A.O. & Standart Sapma & Düzey \\
\hline Ürün bilinci & 4,596 & 0,447 & Yüksek \\
\hline Fiyat Bilinci & 4,449 & 0,550 & Yüksek \\
\hline Bilgi Arayışı & 4,185 & 0,664 & Yüksek \\
\hline Ekolojik Çevre Bilinci & 3,157 & 1,262 & Orta \\
\hline Tüketici Hakları Farkındalı̆̆ı & 2,117 & 0,769 & Düşük \\
\hline
\end{tabular}

[A.O. = (1,00-2,33) Düşük; A.O. = (2,34-3,66) Orta; A. O.= (3,67-5,00) Yüksek] 
Araştırmada kullanılan değişkenlerin ortalamalarının cinsiyete göre farklılık gösterip göstermediğini ortaya koymak amacıyla farklılık analizi (t testi) gerçekleştirilmiştir. Analiz sonuçları Tablo 4'te yer almaktadır. Elde edilen sonuçlara göre tüketici hakları farkındalığı dışında kalan tüm değişkenlerin ortalamaları cinsiyete göre farklılık göstermektedir. Buna göre; farklılık gösteren tüm değişkenlerde kadınların ortalamaları daha yüksektir. Diğer bir ifadeyle kadınların; ürün bilinci, bilgi arayışı, fiyat bilinci ve ekolojik çevre bilinci erkeklere göre daha yüksektir.

Tablo 4. Cinsiyete göre farklılık analizi sonuçları ( $\mathrm{t}$ testi)

\begin{tabular}{lllll}
\hline & \multicolumn{1}{c}{ Cinsiyet } & A.O. & Standart Sapma & p \\
\hline \multirow{2}{*}{ Tüketici Hakları Farkındalığı } & Kadın & 2,088 & 0,768 & \multirow{2}{*}{$>0,05$} \\
\cline { 2 - 4 } & Erkek & 2,141 & 0,771 & \\
\hline \multirow{2}{*}{ Ürün Bilinci } & Kadın & 4,670 & 0,409 & \multirow{2}{*}{$<0,01$} \\
\cline { 2 - 4 } & Erkek & 4,535 & 0,469 & \multirow{2}{*}{$<0,01$} \\
\hline \multirow{2}{*}{ Bilgi Arama } & Kadın & 4,302 & 0,532 & \multirow{2}{*}{$<0,05$} \\
\cline { 2 - 4 } & Erkek & 4,086 & 0,546 & \multirow{2}{*}{$<0,05$} \\
\hline \multirow{2}{*}{ Ekyat Bilinci } & Kadın & 4,527 & 0,660 & \\
\cline { 2 - 4 } & Erkek & 4,383 & 0,662 & \\
\hline
\end{tabular}

Araştırmada kullanılan değişkenlerin ortalamalarının eğitim düzeyine göre farklılık gösterip göstermediğini ortaya koymak amacıyla farklılık analizi (anova testi) gerçekleştirilmiştir. Analiz sonuçları Tablo 5'te yer almaktadır. Elde edilen sonuçlara göre; tüketici hakları farkındalığı, bilgi arayışı ve fiyat bilinci ortalamaları eğitim düzeyine göre farklılık göstermektedir.

Tüketici hakları farkındalığı açısından incelendiğinde lisansüstü eğitim düzeyine sahip olan katılımcıların ortalamalarının daha yüksek olduğu görülmüştür. Post-hoc testi sonucuna göre, farklılık özellikle lisansüstü eğitim almış katılımcılarla lise ve daha alt seviyede eğitim alanlar arasındaki farklılıktan kaynaklanmaktadır. Bilgi arayışı ortalamaları incelendiğinde ise en fazla bilgi arayan grubun ilkokul-ortaokul düzeyinde eğitim görenler olduğu tespit edilmiştir. Post-hoc testi sonucuna göre her bir değişken birbiriyle karşılaştırıldığında anlamlı bir farklılık bulunmamaktadır.

Fiyat bilinci açısından eğitim düzeyine göre ortalamalar incelendiğinde en yüksek ortalamaya sahip katılımcı grubunun ilkokul-ortaokul düzeyinde eğitim görenler olduğu bulgusuna ulaşılmıştır. Post-hoc testi sonucunda da farklılığın genel olarak bu gruptan kaynaklandığı görülmüştür. 
Tablo 5. Eğitim düzeyine göre farklılık analizi sonuçları

\begin{tabular}{|c|c|c|c|c|}
\hline & Ĕgitim Düzeyi & A.O. & Standart Sapma & $\mathbf{p}$ \\
\hline \multirow{6}{*}{$\begin{array}{l}\text { Tüketici Hakları } \\
\text { Farkındalığı }\end{array}$} & İlköğretim & 1,813 & 0,498 & \multirow{6}{*}{$<0,01$} \\
\hline & Lise & 2,034 & 0,773 & \\
\hline & Önlisans & 2,068 & 0,759 & \\
\hline & Lisans & 2,168 & 0,840 & \\
\hline & Lisansüstü & 2,447 & 0,599 & \\
\hline & Toplam & 2,115 & 0,769 & \\
\hline \multirow{6}{*}{ Ürün Bilinci } & İlköğretim & 4,733 & 0,321 & \multirow{6}{*}{$>0,05(, 065)$} \\
\hline & Lise & 4,568 & 0,532 & \\
\hline & Önlisans & 4,590 & 0,490 & \\
\hline & Lisans & 4,550 & 0,448 & \\
\hline & Lisansüstü & 4,672 & 0,337 & \\
\hline & Toplam & 4,598 & 0,446 & \\
\hline \multirow{6}{*}{ Bilgi Arama } & İlköğretim & 4,411 & 0,451 & \multirow{6}{*}{$<0,05$} \\
\hline & Lise & 4,093 & 0,655 & \\
\hline & Önlisans & 4,190 & 0,507 & \\
\hline & Lisans & 4,138 & 0,546 & \\
\hline & Lisansüstü & 4,227 & 0,456 & \\
\hline & Toplam & 4,185 & 0,550 & \\
\hline \multirow{6}{*}{ Fiyat Bilinci } & İlköğretim & 4,825 & 0,353 & \multirow{6}{*}{$<0,01$} \\
\hline & Lise & 4,368 & 0,773 & \\
\hline & Önlisans & 4,585 & 0,583 & \\
\hline & Lisans & 4,316 & 0,675 & \\
\hline & Lisansüstü & 4,505 & 0,609 & \\
\hline & Toplam & 4,450 & 0,664 & \\
\hline \multirow{6}{*}{ Ekolojik Çevre Bilinci } & İlköğretim & 3,386 & 1,152 & \multirow{6}{*}{$>0,05$} \\
\hline & Lise & 2,963 & 1,418 & \\
\hline & Önlisans & 3,327 & 1,134 & \\
\hline & Lisans & 3,112 & 1,284 & \\
\hline & Lisansüstü & 3,210 & 1,131 & \\
\hline & Toplam & 3,156 & 1,264 & \\
\hline
\end{tabular}

Araştırmada kullanılan değişkenlerin ortalamalarının gelir düzeyine göre farklılık gösterip göstermediğini ortaya koymak amacıyla farklılık analizi (anova testi) gerçekleştirilmiştir. Analiz sonuçları Tablo 6'da yer almaktadır. Elde edilen sonuçlara göre; değişkenler arasında bir farklılığa ulaşılmazken, tüketici hakları farkındalığının \%95 güven aralığında farklılık kabul edilebilecek bir değere sahip olduğu söylenebilir $(\mathrm{p}=0,054)$. Buna göre en düşük gelire sahip olan katılımcıların, tüketici hakları farkındalık düzeyleri en düşük grup olduğu görülmektedir. 
Tablo 6. Gelir düzeyine göre farklılık analizi sonuçları

\begin{tabular}{|c|c|c|c|c|}
\hline & Gelir Düzeyi & A.O. & Standart Sapma & $\mathbf{p}$ \\
\hline \multirow{5}{*}{$\begin{array}{l}\text { Tüketici Hakları } \\
\text { Farkındalığı }\end{array}$} & 2500 ve alt1 & 2,025 & 0,730 & \multirow{5}{*}{$>0,05(, 054)$} \\
\hline & $2501-3500$ & 2,045 & 0,676 & \\
\hline & $3501-4500$ & 2,101 & 0,777 & \\
\hline & 4501 ve üstü & 2,293 & 0,864 & \\
\hline & Toplam & 2,117 & 0,769 & \\
\hline \multirow{5}{*}{ Ürün Bilinci } & 2500 ve alt1 & 4,581 & 0,487 & \multirow{5}{*}{$>0,05$} \\
\hline & $2501-3500$ & 4,627 & 0,421 & \\
\hline & $3501-4500$ & 4,598 & 0,423 & \\
\hline & 4501 ve üstü & 4,578 & 0,460 & \\
\hline & Toplam & 4,596 & 0,447 & \\
\hline \multirow{5}{*}{ Bilgi Arama } & 2500 ve alt1 & 4,164 & 0,633 & \multirow{5}{*}{$>0,05$} \\
\hline & $2501-3500$ & 4,252 & 0,542 & \\
\hline & $3501-4500$ & 4,200 & 0,507 & \\
\hline & 4501 ve üstü & 4,120 & 0,506 & \\
\hline & & 4,185 & 0,550 & \\
\hline \multirow{5}{*}{ Fiyat Bilinci } & 2500 ve alt1 & 4,432 & 0,763 & \multirow{5}{*}{$>0,05$} \\
\hline & $2501-3500$ & 4,483 & 0,614 & \\
\hline & $3501-4500$ & 4,488 & 0,654 & \\
\hline & 4501 ve üstü & 4,394 & 0,626 & \\
\hline & Toplam & 4,449 & 0,664 & \\
\hline \multirow{5}{*}{ Ekolojik Çevre Bilinci } & 2500 ve alt1 & 3,176 & 1,228 & \multirow{5}{*}{$>0,05$} \\
\hline & $2501-3500$ & 3,012 & 1,248 & \\
\hline & $3501-4500$ & 3,185 & 1,310 & \\
\hline & 4501 ve üstü & 3,265 & 1,270 & \\
\hline & Toplam & 3,157 & 1,262 & \\
\hline
\end{tabular}

Araştırmada kullanılan değişkenlerin ortalamalarının yaşa göre farklılık gösterip göstermediğini ortaya koymak amacıyla farklılık analizi (anova testi) gerçekleştirilmiştir. Analiz sonuçları Tablo 7'de yer almaktadır. Elde edilen sonuçlara göre; bilgi arama dışındaki tüm değişkenlerin ortalamaları yaşa göre farklılık göstermektedir.

Tüketici hakları farkındalığı ve ekolojik çevre bilinci açısından yaşa göre ortalamalar incelendiğinde en yüksek yaş grubunun (45-45+) en yüksek ortalamaya sahip olduğu görülmektedir. Post-hoc testleri sonucunda her iki değişkende de farklılı̆̆ın 45 yaş ve üstü gruptan kaynaklandığı tespit edilmiştir. Buna göre 45 yaş ve üstü katılımcıların daha fazla tüketici hakları farkındalığı ve ekolojik çevre bilincine sahip olduğu söylenebilir.

Ürün ve fiyat bilinci açısından yaşa göre ortalamalar incelendiğinde, 25 yaş altı katılımcı grubunun en düşük ortalamaya sahip olduğu görülmektedir. Post-hoc testleri sonucunda her iki değişkende de farklılığın 25 yaş altı gruptan kaynaklandığı görülmektedir. Buna göre 25 yaş altı katılımcıların daha düşük düzeyde ürün ve fiyat bilincine sahip olduğu söylenebilir. 
Tablo 7. Yaş düzeyine göre farklılık analizi sonuçları

\begin{tabular}{|c|c|c|c|c|}
\hline & Yaş Düzeyi & A.O. & Standart Sapma & $\mathbf{P}$ \\
\hline \multirow{6}{*}{$\begin{array}{l}\text { Tüketici Hakları } \\
\text { Farkındalığı }\end{array}$} & 25 yaş altı & 1,872 & 0,704 & \multirow{5}{*}{$<0,01$} \\
\hline & $25-34$ & 2,091 & 0,779 & \\
\hline & $35-44$ & 1,956 & 0,649 & \\
\hline & $45-45+$ & 2,470 & 0,773 & \\
\hline & \multirow[t]{2}{*}{ Toplam } & 2,117 & 0,769 & \\
\hline & & 4,596 & & \multirow{6}{*}{$<0,01$} \\
\hline \multirow{5}{*}{ Ürün Bilinci } & 25 yaş altı & 4,423 & 0,500 & \\
\hline & $25-34$ & 4,574 & 0,454 & \\
\hline & $35-44$ & 4,753 & 0,341 & \\
\hline & $45-45+$ & 4,641 & 0,423 & \\
\hline & \multicolumn{2}{|l|}{ Toplam } & 0,447 & \\
\hline \multirow{5}{*}{ Bilgi Arama } & 25 yaş altı & 4,090 & 0,631 & \multirow{5}{*}{$>0,05(0,052)$} \\
\hline & $25-34$ & 4,157 & 0,565 & \\
\hline & $35-44$ & 4,333 & 0,475 & \\
\hline & $45-45+$ & 4,185 & 0,495 & \\
\hline & Toplam & 4,185 & 0,550 & \\
\hline \multirow{5}{*}{ Fiyat Bilinci } & 25 yaş altı & 4,041 & 0,816 & \multirow{5}{*}{$<0,01$} \\
\hline & $25-34$ & 4,441 & 0,636 & \\
\hline & $35-44$ & 4,661 & 0,526 & \\
\hline & $45-45+$ & 4,600 & 0,539 & \\
\hline & Toplam & 4,449 & 0,664 & \\
\hline \multirow{5}{*}{ Ekolojik Çevre Bilinci } & 25 yaş altı & 2,761 & 1,274 & \multirow{5}{*}{$<0,01$} \\
\hline & $25-34$ & 2,966 & 1,251 & \\
\hline & $35-44$ & 3,264 & 1,259 & \\
\hline & $45-45+$ & 3,693 & 1,095 & \\
\hline & Toplam & 3,157 & 1,262 & \\
\hline
\end{tabular}

Araştırmada kullanılan değişkenlerin ortalamalarının meslek türlerine göre farklılık gösterip göstermediğini ortaya koymak amacıyla farklılık analizi (anova testi) gerçekleştirilmiştir. Analiz sonuçları Tablo 8'de yer almaktadır. Buna göre bilgi arayışı dışındaki tüm değişkenlerin ortalamalarında farklılık görülmektedir.

Tüketici hakları farkındalığı ve ekolojik çevre bilinci açısından meslek türlerine göre ortalamalar incelendiğinde emeklilerin en yüksek ortalamaya sahip olduğu tespit edilmiştir. Post-hoc testleri sonucunda her iki değişkende de farklılığın emeklilerden kaynaklandığı sonucuna ulaşılmıştır. Buna göre emeklilerin daha fazla tüketici hakları farkındalığı ve çevre bilincine sahip olduğu söylenebilir.

Ürün ve fiyat bilinç düzeylerinde en düşük ortalamaya sahip katılımcı grubunun öğrenciler olduğu görülmektedir. Post-hoc testleri sonucunda fiyat bilincindeki farklılığının öğrencilerden kaynaklandığ 1 ve ürün bilincindeki farklılığın ise her bir değişken açısından farklılık göstermediği görülmektedir. Bu sonuçlara göre özellikle öğrencilerin diğer mesleki durumlardan farklı olarak daha düşük düzeyde fiyat bilincine sahip olduğu söylenebilir. 
Tablo 8. Meslek türlerine göre farklılık analizi sonuçları

\begin{tabular}{|c|c|c|c|c|}
\hline & Mesleki Durum & A.O. & Standart Sapma & $\mathbf{P}$ \\
\hline \multirow{5}{*}{$\begin{array}{l}\text { Tüketici Hakları } \\
\text { Farkındalığı }\end{array}$} & Öğrenci & 1,887 & 0,637 & \multirow{5}{*}{$<0,01$} \\
\hline & Özel Sektör & 2,102 & 0,783 & \\
\hline & Kamu Çalışanı & 2,237 & 0,802 & \\
\hline & Emekli & 2,628 & 0,736 & \\
\hline & Toplam & 2,146 & 0,781 & \\
\hline \multirow{5}{*}{ Ürün Bilinci } & Öğrenci & 4,438 & 0,457 & \multirow{5}{*}{$<0,05$} \\
\hline & Özel Sektör & 4,607 & 0,464 & \\
\hline & Kamu Çalışanı & 4,600 & 0,404 & \\
\hline & Emekli & 4,661 & 0,415 & \\
\hline & Toplam & 4,583 & 0,453 & \\
\hline \multirow{5}{*}{ Bilgi Arama } & Öğrenci & 4,086 & 0,599 & \multirow{4}{*}{$>0,05$} \\
\hline & Özel Sektör & 4,179 & 0,549 & \\
\hline & Kamu Çalışanı & 4,165 & 0,545 & \\
\hline & Emekli & 4,256 & 0,526 & \\
\hline & Toplam & 4,170 & 0,554 & \\
\hline \multirow{5}{*}{ Fiyat Bilinci } & Öğrenci & 4,076 & 0,705 & \multirow{5}{*}{$<0,01$} \\
\hline & Özel Sektör & 4,461 & 0,661 & \\
\hline & Kamu Çalışanı & 4,475 & 0,692 & \\
\hline & Emekli & 4,693 & 0,456 & \\
\hline & Toplam & 4,424 & 0,673 & \\
\hline \multirow{5}{*}{ Ekolojik Çevre Bilinci } & Öğrenci & 2,877 & 1,335 & \multirow{5}{*}{$<0,01$} \\
\hline & Özel Sektör & 3,004 & 1,193 & \\
\hline & Kamu Çalışanı & 3,358 & 1,321 & \\
\hline & Emekli & 4,163 & 0,886 & \\
\hline & Toplam & 3,168 & 1,263 & \\
\hline
\end{tabular}

Tüketici bilincini ortaya koyan boyutların tümü (ürün bilinci- fiyat bilinci, ekolojik çevre bilinci- bilgi düzeyi) ele alındığında, katılımcıların tüketici bilinç düzeyinin yüksek olduğu görülmektedir. Demografik değişkenlere göre farklılık analizi sonuçları Tablo 9' da yer almaktadır. Buna göre katılımcıların tüketici bilinç düzeyi cinsiyet, eğitim, yaş ve meslek değişkenlerine göre farklılık göstermekte ancak gelire göre farklılık göstermemektedir. 
Tablo 9. Demografik değişkenlere göre tüketici bilinci düzeyi

\begin{tabular}{|c|c|c|c|c|}
\hline \multicolumn{2}{|c|}{ Değişken } & \multirow{2}{*}{$\begin{array}{l}\text { A.O. } \\
4,249\end{array}$} & \multirow{2}{*}{$\begin{array}{c}\text { Standart Sapma } \\
0,470\end{array}$} & \multirow{3}{*}{$\begin{array}{c}\mathbf{P} \\
<0,01\end{array}$} \\
\hline \multirow{2}{*}{ Cinsiyet } & Kadın & & & \\
\hline & Erkek & 4,060 & 0,509 & \\
\hline \multirow{6}{*}{ Eğitim Düzeyi } & İlköğretim & 4,389 & 0,396 & \multirow{5}{*}{$<0,01$} \\
\hline & Lise & 4,053 & 0,613 & \\
\hline & Önlisans & 4,217 & 0,444 & \\
\hline & Lisans & 4,077 & 0,488 & \\
\hline & Lisansüstü & 4,203 & 0,393 & \\
\hline & Toplam & 4,147 & 0,502 & \multirow{5}{*}{$>0,05$} \\
\hline \multirow{5}{*}{ Gelir Düzeyi } & 2500 ve alt1 & 4,136 & 0,540 & \\
\hline & $2501-3500$ & 4,150 & 0,483 & \\
\hline & $3501-4500$ & 4,167 & 0,491 & \\
\hline & 4501 ve üstü & 4,133 & 0,492 & \\
\hline & Toplam & 4,146 & 0,500 & \\
\hline \multirow{5}{*}{ Yaş Düzeyi } & 25 yaş altı & 3,885 & 0,531 & \multirow{4}{*}{$<0,01$} \\
\hline & $25-34$ & 4,091 & 0,471 & \\
\hline & $35-44$ & 4,305 & 0,458 & \\
\hline & $45-45+$ & 4,311 & 0,457 & \\
\hline & Toplam & 4,146 & 0,500 & \\
\hline \multirow{5}{*}{ Mesleki Durum } & Öğrenci & 3,922 & 0,477 & \multirow{4}{*}{$<0,01$} \\
\hline & Özel Sektör & 4,118 & 0,490 & \\
\hline & Kamu Çalışanı & 4,191 & 0,518 & \\
\hline & Emekli & 4,458 & 0,443 & \\
\hline & Toplam & 4,146 & 0,500 & \\
\hline
\end{tabular}

[A.O. = $(1,00-2,33)$ Düşük; A.O. = $(2,34-3,66)$ Orta; A. O.= $(3,67-5,00)$ Yüksek]

Araştırmada kullanılan değişkenlerin ortalamalarının tüketici hakları farkındalığı düzeylerine göre farklılık gösterip göstermediğini ortaya koymak amacıyla farklılık analizi (anova testi) gerçekleştirilmiştir. Analiz sonuçları Tablo 10'da yer almaktadır. Buna göre tüketici hakları farkındalığı düzeylerinin ortalamaları her bir değişkende kendi aralarında farklılık göstermektedir.

Post- hoc testi sonuçlarına göre ürün bilinci ve fiyat bilinci ortalamalarında her bir değişken için farklılık görülmektedir. Bilgi arama ve ekolojik çevre bilincinde farklılık yüksek ve düşük düzeyler arasındaki farklılıktan kaynaklanmaktadır. Bu sonuçlara göre tüketici hakları farkındalığı düşük olanların ürün ve fiyat bilinci ile bilgi arayışı ortalamaları daha yüksektir. Diğer yandan tüketici hakları farkındalığı düşük olanların ekolojik çevre bilinci daha düşüktür.

Tablo 10. Tüketici hakları farkındalığı düzeylerine göre farklılık analizi sonuçları

\begin{tabular}{lcccc}
\hline & \multicolumn{4}{c}{ Tüketici Hakları Farkındalı̆̆ } \\
\hline & Düşük & Orta & Yüksek & P \\
\hline Ürün Bilinci & 4,646 & 4,640 & 4,419 & $<0,01$ \\
\hline Bilgi Arayış1 & 4,269 & 4,160 & 3,938 & $<0,01$ \\
\hline Fiyat Bilinci & 4,503 & 4,582 & 4,210 & $<0,01$ \\
\hline Ekolojik Çevre Bilinci & 2,938 & 3,544 & 3,625 & $<0,01$ \\
\hline
\end{tabular}




\section{SONUÇ}

Denizli ilinde tüketicilerin tüketici hakları farkındalığını ve tüketici bilinç düzeyini tespit etmeye yönelik yapılan bu çalışmada katılımcıların bilgi ve tutumları değerlendirilmiştir. Araştırma sonuçlarına göre katılımcıların, tüketici hakları konusunda yeterli seviyede bilgi sahibi olmadıkları görülmüştür. Bu sonuç Altunışık vd. (2004) ve Nart (2008)'ın tüketici hakları konusunda farkındalık düzeyini ortaya koymak amacıyla yaptıkları araştırma sonuçları ile örtüşmektedir. Buna göre tüketicilerin büyük çoğunluğunun sahip olduğu haklardan haberdar olmadığı sonucuna varılmıştır. Ayrıca araştırmada yer alan tüketici bilinç düzeyini belirleyen boyutlar açısından sonuçlar incelendiğinde; tüketicilerin ekolojik çevre bilinci orta düzeyde, ürün bilinci, fiyat bilinci ve bilgi arayışının yüksek düzeyde olduğu görülmüştür. Gülmez (2006) yaptığı benzer bir araştırmada ürün ve fiyat farkındalığına sahip olanların oranının \%60' lar civarında olduğunu ortaya koymuştur.

Elde edilen bulgular katılımcıların tüketici hakları farkındalık düzeyinin cinsiyet dışındaki tüm demografik değişkenlere göre farklılık gösterdiğini ortaya çıkarmıştır. Eğitim değişkenine göre farklılığın, lisansüstü eğitim alanlar ile lise ve daha alt düzeyde eğitim alan katılımcılar arasında olduğu görülmektedir. Tüketicilerin eğitim düzeylerinin artmasıyla birlikte tüketici hakları farkındalık düzeylerinin de arttığı söylenebilir. Elde edilen bu bulgu Cunningham ve Cunnigham (1976), Dickinson ve Shaver (1982), Rousseau ve Venter (1995), Gülmez (2006), Kaynak ve Akan (2011)'nın çalışmalarıyla benzerlik göstermektedir. Aynı şekilde tüketicilerin gelir düzeyleri ile tüketici hakları farkındalık düzeyleri arasında aynı yönde doğru orantılı bir ilişki olduğu saptanmıştır. Elde edilen bu bulgu yine Rousseau ve Venter (1995), Nart (2008) ve Kaynak ve Akan (2011) tarafından yapılan çalışmalarla ile benzerlik göstermektedir. Barksdale ve Darden (1972) ile Nart' in (2008) yapmış oldukları çalışmadan farklı olarak, yaşlıların gençlere göre daha yüksek farkındalık düzeyine sahip olduğu görülmüştür. Şahin ve Kor (2009)'un yaptıkları çalışmada tespit edildiği gibi emekli katılımcılar, diğer meslek gruplarına göre daha yüksek farkındalık düzeyine sahiptirler. Emekli ve yaşlı katılımcıların diğer gruplara göre daha yüksek farkındalık düzeyine sahip olmalarının nedeni, yaşam tecrübelerinin fazla olmasından ve alışverişe daha çok zaman ayırmalarından kaynaklanıyor olabilir.

Araştırma sonuçlarına göre elde edilen bir diğer bulgu ürün bilincinin sadece cinsiyet ve yaş değişkenlerine göre farklılık göstermiş olmasıdır. Kadın katılımcıların erkeklere göre daha yüksek ürün bilincine sahip olduğu görülmektedir. Ayrıca yaş değişkenine göre farklılığın 25 yaş altı katılımcılardan kaynaklandığı ve gençlerin yaşlılara göre ürün bilinci düzeylerinin daha düşük ortalamaya sahip olduğu tespit edilmiştir. Katılımcılar bilgi arayışı boyutu ile incelendiğinde ise yalnızca cinsiyet ve eğitim değişkenlerine göre farklılık olduğu görülmektedir. Eğitim değişkenine göre ilkokul-ortaokul düzeyinde eğitimi olan katılımcılar bilgi arayışında daha yüksek ortalamaya sahiptir. Ayrıca kadınların erkeklere göre daha fazla bilgi arayış çabasında olduğu görülmektedir. Kadınların ürün bilincinin ve bilgi arayışının erkeklere oranla yüksek çıkmasının nedeni, kadın tüketicilerin alışverişi sevmesi ve alışverişte daha fazla zaman harcamak istemesi olabilir.

Araştırma sonuçlarına göre katılımcıların fiyat bilinci cinsiyet, eğitim, yaş ve meslek değişkenlerine göre farklılık göstermektedir. Kadın katılımcıların erkeklere göre, daha yüksek fiyat bilincine sahip olduğu görülmektedir. Diğer değişkenlere bakıldığında, gençlerin 
yaşlılara, öğrencilerin de diğer meslek gruplarına göre fiyat bilinci düzeylerinin daha düşük düzeyde olduğu sonucuna ulaşılmıştır. Bu tüketici gruplarını oluşturan bireylerin büyük çoğunluğunun henüz kendi kazançlarını sağlamıyor olması, tüketim alanlarının ve sıklıklarının çok yoğun olmaması fiyat bilinçlerinin daha düşük düzeyde çıkmasına sebep olmuş olabilir.

Katılımcıların ekolojik çevre bilinç düzeyi açısından farklılık bulunan değişkenler; cinsiyet, yaş ve meslek olarak görülmüştür. Elde edilen sonuçlara göre kadınların ekolojik çevre bilinç düzeylerinin tüm boyutlarda olduğu gibi erkeklerden daha yüksek olduğu ortaya çıkmıştır. Araştırmada edinilen bu bulgu Çabuk vd. (2008) ve Huang vd. (2014) çalışmaları ile benzerlik göstermektedir. Diğer değişkenler açısından farklılığın, 45 yaş ve üstü tüketici grubundan ve emeklilerden kaynaklandığı tespit edilmiştir. Araştırma sonuçlarına göre tüketicilerin yaş aldıkça ekolojik çevre bilinç düzeylerinin arttığı görülmektedir. Nakıboğlu (2007)'nun yaptığı çalışma bu sonucu destekler niteliktedir. Ayrıca meslek grupları açısından ekolojik çevre bilinç düzeyine bakıldığında, emeklilerin yine diğer meslek gruplarına göre oldukça önemli bir farkla çevre bilincinin daha yüksek olduğu sonucu ortaya çıkmıştır.

Tüketici bilinci tüm boyutlarıyla birlikte değerlendirildiğinde, gelir dışındaki tüm değişkenlere göre farklılık göstermektedir. Mesleki açıdan emekli katılımcıların, eğitim değişkenine göre ilköğretim düzeyinde eğitim görmüş katılımcıların tüketici bilinç düzeyi yüksek düzeyde çıkmıştır. Erkek katılımcıların kadınlara göre, genç katılımcıların yaşlılara göre tüketici bilinç düzeylerinin daha düşük seviyede olduğu tespit edilmiştir.

Katılımcıların tüketici hakları farkındalık düzeylerine göre tüketici bilinç düzeyini belirleyen boyutların ortalamalarının farklılık gösterdiği bulgusu elde edilmiştir. Katılımcıların sahip oldukları haklar konusundaki farkındalık düzeyleri ile ekolojik çevre bilinç düzeyleri arasında aynı yönde bir ilişki belirlenmiştir. Bu durumun aksine katılımcıların sahip oldukları haklar konusundaki farkındalık düzeyleri ile ürün bilinci, fiyat bilinci ve bilgi arayışı arasında ters yönde bir ilişki ortaya çıkmıştır. Bir diğer ifade ile katılımcıların tüketici hakları konusundaki farkındalık düzeyleri arttıkça ekolojik çevre bilinç düzeylerinin arttığı; ürün bilinci, bilgi arayışı ve fiyat bilinçlerinin ise azaldığı söylenebilir.

Genel olarak sonuçlar incelendiğinde katılımcıların bilinçli satın almaya yönelik tutum ve davranışları benimsemelerine rağmen tüketici hakları konusunda yeterli düzeyde farkındalık sahibi olmadıkları görülmektedir. Hâlbuki tüketicilerin bilinçli hareket etmesindeki en büyük faktör tüketici hakları konusunda bilgi düzeylerinin artmasıdır. Bu açıdan tüketiciler bilinçli tüketime yönelik her ne kadar istekli olurlarsa olsunlar tüketim ve tüketici hakları ile ilgili gerekli bilgilerin farkına varmadıkları sürece bunu tam olarak gerçekleştiremeyeceklerdir.

Tüketicilerin sahip oldukları haklar konusundaki farkındalık düzeyleri yükseldikçe hem kendilerini çeşitli mağduriyetlere karşı koruyabilme yetenekleri artacak hem de istek ve ihtiyaçlarını karşılamaya yönelik satın alma süreci içerisinde yoğun bir çaba harcama gerekliliği hissetmeyeceklerdir. Bu durumda tüketiciler kendileri adına gereksiz vakit ve nakit kaybı yaşamayarak toplum, gelecek nesiller, çevre ve sağlık gibi konularda daha bilinçli bireyler konumuna gelebilirler.

Tüketicilerin bilinçli tüketime eğilimi olmasına rağmen tüketici hakları farkındalık düzeylerinin gelişmemiş olmasının temel sebebi eğitim olarak görülebilir. Tüketicilerin bu 
konuda ilköğretim düzeyinden itibaren gerekli eğitimleri görmeye başlaması, bilinçli tüketim olayını bütünüyle kavramalarını ve tüketici haklarının önemini benimsemelerini sağlayabilir. Ayrıca tüketicilere haklarını bilmedikleri takdirde, bilinçli tüketimi gerçekleştirmelerinin ve çeşitli mağduriyetlere karşı kendilerini koruyabilmelerinin zor olduğu sürekli hatırlatılmalıdır. Devlet bu konuyu daha ciddi boyutta ele almalı, milli eğitim kurumlarında "tüketici hakları ve bilinçli tüketim" gibi zorunlu dersler konulmalıdır. Hatta tüketiciler için farklı bilgilendirme faaliyetleri ve etkinlikleri düzenlemeli, tüketici örgütlerinin çoğalması ve yaygınlaşması için destek verilmelidir. Toplumun uzun vadeli refahını sağlamak için; devlet ve sivil toplum kuruluşlarının işbirliği yapması, temek haklarını bilen, mevcut kaynaklarını etkin kullanabilen bilinçli tüketici sayısını artırmaya yönelik çabalaması gerekmektedir.

\section{KAYNAKÇA}

Altunışık, R., Mert, K., \& Nart, S. (2004). Türkiye'de Tüketici Koruma Faaliyetleri: Tüketici Algılarına Yönelik Bir Saha Çalışması. 3. Ulusal Bilgi, Ekonomi ve Yönetim Kongresi, 475484 .

Anderson Jr, W. T., \& Cunningham, W. H. (1972). The Socially Conscious Consumer. Journal of Marketing, 36(3), 23-31.

Aracioglu, B., \& Tatlidil, R. (2009). Tüketicilerin Satın Alma Davranışında Çevre Bilincinin Etkileri", Ege Academic Review, 9(2), 435-461.

Arıkan, R., Odabaşı, Y., \& Gürgen, H. (1996). Tüketici Davranışları ve Tüketici Bilinci. T.C Anadolu Üniversitesi.

Aslan, İ. Y. (2016). Bankacılar İçin Tüketici Hukuku. İstanbul, Bankalar Arası Kart Merkezi. Aryan Basım Tanıtım ve Matbaa, İstanbul

Ay, C., \& Ecevit, Z. (2005). Çevre Bilinçli Tüketiciler. Akdeniz University Faculty of Economics $\mathcal{E}$ Administrative Sciences Faculty Journal/Akdeniz Universitesi Iktisadi ve Idari Bilimler Fakultesi Dergisi, 5(10), 238-263.

Bakke, A. J., Shehan, C. V., \& Hayes, J. E. (2016). Type of Milk Typically Consumed, and Stated Preference, But Not Health Consciousness Affect Revealed Preferences For Fat in Milk. Food Quality and Preference,49, 92-99.

Baldwin, G., \& James, R. (2000). The Market in Australian Higher Education and the Concept of Student as Informed Consumer. Journal of Higher Education Policy and Management, 22(2), 139-148.

Barksdale, H. C., \& Darden, W. R. (1972). Consumer Attitudes Toward Marketing and Consumerism. The Journal of Marketing, 36(4), 28-35.

Baykan, R. (1996). Türkiye'de Tüketicinin Korunması Tedbirleri. İstanbul Ticaret Odası Yayınları, İstanbul.

Bektas, Z. K., Miran, B., Uysal, O. K., \& Gunden, C. (2011). Consumer Awareness for Food Safety in Turkey. Bulgarian Journal of Agricultural Science,17(4), 470-483. 
Bener, Ö., \& Babaoğul, M. (2008). Sürdürülebilir Tüketim Davranışı ve Çevre Bilinci Oluşturmada Bir Araç Olarak Tüketici Eğitimi. Hacettepe Üniversitesi Sosyolojik Araştırmalar E-Dergisi, 5(1), 1-10.

Brooker, G. (1976). The Self-actualizing Socially Conscious Consumer. Journal of Consumer Research, 3(2), 107-112.

Buğday E. B., \& Babaoğul, M. (2016). Bilinçli Tüketim Kavramının Boyutları: Bilinçli Tüketim Davranışının Yeniden Tanımlanması. Sosyoekonomi, 24(30), 187-206.

Carr, D. J., Gotlieb, M. R., Lee, N. J., \& Shah, D. V. (2012). Examining Overconsumption, Competitive Consumption, and Conscious Consumption from 1994 to 2004: Disentangling Cohort and Period Effects. The ANNALS of the American Academy of Political and Social Science, 644(1), 220-233.

Cunningham, W. H., \& Cunningham, I. C. (1976). Consumer Protection: More Information or More Regulation?. The Journal of Marketing, 40(2), 63-68.

Çabuk, S., Nakıboğlu, B., \& Keleş, C. (2008). Tüketicilerin Yeşil (Ürün) Satın Alma Davranışlarının Sosyo-Demografik Değişkenler Açısından İncelenmesi. Çukurova Üniversitesi Sosyal Bilimler Enstitüsü Dergisi, 17(1), 85-102.

Dickinson, H. V. \& Shaver P. J. (1982). A Test of Consumer Awareness For Adults. The Journal of Consumer Affairs, 16(2), 241-260.

Dutta-Bergman, M. J. (2004). Primary Sources of Health Information: Comparisons in The Domain of Health Attitudes, Health Cognitions and Health Behaviors. Health Communication, 16, 273-288.

Ferman, M. (1993). Tüketicinin Korunmasına Gelişimci Bir Yaklaşım. İstanbul Ticaret Odası Yayınları, İstanbul.

Fraj, E., \& Martinez, E. (2006). Environmental Values and Lifestyles as Determining Factors of Ecological Consumer Behaviour: An Empirical Analysis. Journal of Consumer Marketing, 23(3), 133-144.

Gegez, A. E. (2007). Pazarlama araştırmaları. Beta Basım Yayım Dağıtım AŞ.

González, C., Johnson, N., \& Qaim, M. (2009). Consumer Acceptance of Second-Generation GM Foods: The Case of Biofortified Cassava in the Northeast of Brazil. Journal of Agricultural Economics, 60(3), 604-624.

Göle, C., (1979). AET ve Tüketicinin Korunması. Ankara Üniversitesi SBF Dergisi, 34(1), 175-192.

Gülmez, M. (2006). Pazarlama Yönü İtibariyle Bilinçli Tüketim ve Bilinçli Tüketiciye Yönelik Bir Saha Araştırması. Selçuk Üniversitesi Sosyal Bilimler MYO Dergisi, 9(1-2), 153-178.

Hayta, A. B. (2007). Tüketicinin Korunmasında Tüketici Örgütlerinin Rolü ve Önemi. Kastamonu Ĕ̆itim Dergisi, 15(1), 13-20.

Huang, H. C., Lin, T. H., Lai, M. C., \& Lin, T. L. (2014). Environmental Consciousness and Green Customer Behavior: An Examination of Motivation Crowding Effect. International Journal of Hospitality Management, 40, 139-149. 
Ibarra, V. C., \& Revilla, C. D. (2014). “Consumers Awareness on Their Eight Basic Rights: A Comparative Study of Filipinos in the Philippines and Guam", International Journal of Management and Marketing Research, 7(2), 65-78.

Jang, Y. J., Kim, W. G., \& Lee, H. Y. (2015). Coffee Shop Consumers' Emotional Attachment And Loyalty to Green Gtores: The Moderating Role of Green Consciousness. International Journal of Hospitality Management, 44, 146-156.

Jay-Russell, M. T. (2010). ‘Raw (Unpasteurized) Milk: Are Health-conscious Consumers Making An Unhealthy Choice?. Clinical Infectious Diseases, 51(12), 1418-1419.

Kaynak, S., \& Akan, Y. (2011). Tüketicinin Korunmasında Tüketici Bilinç Düzeyinin Önemi: Hane Halkları Üzerine Bir Uygulama. University of Gaziantep Journal of Social Sciences, 10(1), 41-61.

Kaynak, R., \& Ekşi, S. (2014). Effects of Personality, Environmental and Health Consciousness on Understanding the Anti-consumptional Attitudes. Procedia-Social and Behavioral Sciences, 114, 771-776.

Kozinets, R. V., \& Handelman, J. M. (2004). Adversaries of Consumption: Consumer Movements, Activism, and Ideology. Journal of Consumer Research, 31(3), 691-704.

Kumar, M. V. (2016). An Assessment of Consumer Awareness and Protection. A Peer-Reviewed Bi-monthly Bi-lingual Research Journal, 2(4), 338-343.

Makanyeza, C. (2015). Consumer Awareness, Ethnocentrism and Loyalty: An Integrative Model. Journal of International Consumer Marketing, 27(2), 167-183.

Mayer, R. N. (1976).The Socially Conscious Consumer-Another Look at the Data. Journal of Consumer Research, 3(2), 113-115.

Mohan, S., \& Suganthi, V. (2013). Rural Consumers' Awareness About Consumers' Rights. International Journal of Innovative Research and Development, 2(11), 136-141.

Mohr, L. A., Webb, D. J., \& Harris, K. E. (2001). Do Consumers Expect Companies to be Socially Responsible? The Impact of Corporate Social Responsibility On Buying Behavior. Journal of Consumer Affairs, 35(1), 45-72.

Nakıboğlu, B. (2007). Tüketimin Çevreci Boyutu: Çevreci Tutum ve Davranışlara Göre Pazar Bölümlemesi. Çukurova Üniversitesi Sosyal Bilimler Enstitüsü Dergisi, 16(2), 423-438.

Nart, S. (2008). Tüketici Haklarının Pazar Ortamındaki Fonksiyonelliği: Hak Arama Davranışı ve Bilgi, Bilinç, Tutum İlişkisi. Yönetim ve Ekonomi Araştırmaları Dergisi, 6(10), 2-30.

Özmumcu, S. (2014). 6502 Sayılı Tüketicinin Korunması Hakkında Kanun'un Hükümleri ve Yargıtay Kararları Çerçevesinde Tüketici Mahkemelerinin Görev Alanına Giren Uyuşmazlıklara Genel Bir Bakış. Dokuz Eylül Üniversitesi Hukuk Fakültesi Dergisi, Özel Sayı, Cilt 16, 831-871.

Rousseau, G. G., \& Venter, D. J. L. (1995). Measuring Consumer Awareness in Zimbabwe. SA Journal of Industrial Psychology, 21(1), 18-24. 
Schlegelmilch, B. B., Bohlen, G. M., \& Diamantopoulos, A. (1996). The Link Between Green Purchasing Decisions and Measures of Environmental Consciousness. European Journal of Marketing, 30(5), 35-55.

Shieh, J. Y., Chen, J. H., Chang, S. H., \& Lai, C. C. (2014). Environmental Consciousness, Economic Growth, and Macroeconomic Instability. International Review of Economics $\mathcal{E}$ Finance, 34, 151-160.

Singh, N. (2009). Exploring Socially Responsible Behaviour of Indian Consumers: An Empirical İnvestigation. Social Responsibility Journal, 5(2), 200-211.

Straughan, R. D., \& Roberts, J. A. (1999). Environmental Segmentation Alternatives: A Look at Green Consumer Behavior in The New Millennium. Journal of Consumer Marketing, 16(6), 558-575.

Şahin, A., \& Kor, Ö. (2009). Mersin'de Yaşayan Tüketicilerin Tüketici Hakları Konusundaki Bilinç Düzeylerini Etkileyen Faktörleri İnceleyen Bir Araştırma. Anadolu University Journal of Social Sciences, 9(2), 105-125.

Webster, F. E., Jr. (1975). Determining the Characteristics of the Socially Conscious Consumer. Journal of Consumer Research, 2(3), 188-196.

Yüce, A. (2013). Kollektivist Kültür Değerinin Sosyal Sorumlu Tüketim Üzerine Etkisini Belirlemeye Yönelik Bir Araştırma. Atatürk Üniversitesi Sosyal Bilimler Enstitüsü Dergisi, 17(2), 275-291.

http://www.tudef.org.tr/evrenseltuketicihaklari/evrensel.tuketici.haklari.html, Tüketici Derneği Federasyonu, (Erişim tarihi 06.07.2019) 